\title{
PENINGKATAN KEMAMPUAN PENALARAN DAN KOMUNIKASI STATISTIK MAHASISWA MELALUI PEMBELAJAAN STATISTIK INFERENSIAL BERBASIS PROYEK DENGAN MENINJAU GAYA KOGNITIF MAHASISWA
}

\author{
Eva Dwika Masni ${ }^{1}$, Uke Ralmugiz ${ }^{2}$, Nia Kurniaty Rukman ${ }^{3}$ \\ Universitas Muhammadiyah Kupang ${ }^{1,2,3}$ \\ eva.masni070709@gmail.com ${ }^{1}$
}

\begin{abstract}
Abstrak
Penelitian ini merupakan penelitian quasi experimental design dengan menggunakan model Pembelajaran Berbasis Proyek. Rancangan eksperimen yang digunakan adalah one group only pretest-posttest design. Tujuan yang diharapkan dari penelitian ini adalah mengetahui (a) Apakah terdapat perbedaan peningkatan kemampuan penalaran statistik antara mahasiswa yang memiliki gaya kognitif FI dan FD (b) Apakah terdapat perbedaan peningkatan kemampuan komunikasi statistik antara mahasiswa yang memiliki gaya kognitif FI dan FD (c) Apakah terdapat korelasi antara kemampuan penalaran statistik mahasiswa dan kemampuan komunikasi statistik mahasiswa. Populasi dalam penelitian ini adalah mahasiswa program studi pendidikan matematika Universitas Muhammadiyah Kupang tahun akademik 2019/2020. Teknik pengambilan sampel dengan menggunakan teknik purposive sampling dengan memilih semua mahasiswa yang sedang mengontrak mata kuliah statistika inferensial.Beberapa Instrumen penelitian yang dikembangkan yakni (1) Test GEFT (2) instrumen tes kemampuan penalaran statistik (3) instrumen tes kemampuan komunikasi statistik. Data yang telah dikumpulkan dianalisis secara kuantitatif deksriptif. Data mengenai peningkatan kemampuan penalaran dan komunikasi statistik dianalisis dengan statistika inferensial menggunakan uji independent sample $t$ tes, untuk menganalisis keeratan hubungan keamampuan penalaran dan komunikasi statistik digunakan uji korelasi Product Moment Pearson. Hasil penelitian menunjukkan: a) Terdapat perbedaan peningkatan kemampuan penalaran statistik antara mahasiswa yang memiliki gaya kognitif FI dan FD (b) Terdapat perbedaan peningkatan kemampuan komunikasi statistik antara mahasiswa yang memiliki gaya kognitif FI dan FD (c) Terdapat korelasi yang kuat antara kemampuan penalaran statistik mahasiswa dan kemampuan komunikasi statistik mahasiswa dengan koefisien korelasi sebesar 0,683.
\end{abstract}

Kata Kunci: PBP, penalaran statistik, komunikasi statistik, gaya kognitif.

\section{A. Pendahuluan}

Mata kuliah statistik terdiri atas statistika deskriptif dan Inferensial. Keduanya memberikan pedoman dalam memahami materi tentang analisis 
statistik, pengajuan hipotesis dan aplikasinya dalam penelitian yang kelak dapat dijadikan sebagai dasar pegalaman dalam melakukan penelitian untuk memenuhi kewajiban mahasiswa menyelesaikan studinya di Perguruan Tinggi.

Salah satu tujuan pembelajaran statistika adalah mengembangkan kemampuan penalaran statistik. Kemampuan ini terkait dengan kemampuan seseorang dalam memahami konsep dasar, logika penalaran statistik, kemampuan praktis dalam memilih, menghasilkan, menafsirkan metode deskriptif dan inferensial dengan cara yang tepat. Sariningsih (2017)

Sayangnya, fakta di lapangan menunjukkan bahwa kemampuan penalaran statistik mahasiswa masih kurang. Berdasarkan observasi terhadap 21 mahasiswa yang telah memprogram mata kuliah statistika deskriptif sebagai mata kuliah prasyarat untuk mata kuliah statistika inferensial jurusan pendidikan matematika UMK diperoleh hanya 4 orang atau sekitar 19,04\% yang memahami materi statistika dan mampu memberikan penjelasan dengan baik. Beberapa kelemahan mahasiswa dalam memaknai atau menginterpretasi materi statistika terletak pada: penggolongan jenis data, komunikasi data, ukuran data, sampel, populasi, dan pengujian hipotesis. Hal ini menunjukkan rendahnya kemampuan penalaran mahasiswa yang berimplikasi pada rendahnya kemampuan interpretasi atau komunikasi statistiknya.

Kemampuan penalaran guru matematika pada materi statistik deskriptif tentang ukuran letak, populasi, sampel dikategorikan sangat rendah. Berdasarkan data Lanali (2015) Skor pencapaian kemampuan penalaran statistis mahasiswa mencapai 12,23 dengan simpangan baku 5,58 dari skor maksimal ideal 40, tingkat kemampuan penalaran statistis mahasiswa hanya sebesar $30,75 \%$.

Dalam melakukan analisis, interpretasi hingga membuat kesimpulan, kemampuan yang juga harus dikuasai mahasiswa adalah komunikasi. Haerudin (2013) menyatakan kemampuan komunikasi yang baik memungkinkan siswa aktif dalam proses pembelajaran dan memudahkannya dalam memberikan penalaran membantu dalam pembangunan makna dan pempublikasian ide. Melalui komunikasi akan terlihat sejauh mana mahasiswa dapat mengeksplorasi pemikiran dan pemahaman mereka khususnya terhadap materi statistik. 
Rendahnya kemampuan penalaran yang berakibat pada rendahnya komunikasi statistik mahasiswa menuntut kreativitas dosen untuk meningkatkan kualitas pembelajaran guna peningkatan kemampuan mahasiswa terhadap konten statistik. Studi pendahuluan Lanani (2015) menunjukkan bahwa rata-rata kemampuan komunikasi statistis mahasiswa tadris matematika pada salah satu perguruan tinggi di Kota Ternate sebesar 13,88 dengan simpangan baku 7,26 dari skor maksimal ideal 40. Hasil studi tersebut memberikan kesimpulan bahwa kemampuan komunikasi statistis mahasiswa masih rendah dan perlu ditingkatkan. Salah satu faktor penyebab rendahnya kemampuan komunikasi statistik mahasiswa dikarenakan belum terbiasanya siswa dalam menulis teknis tentang statistik dan belum memahami materi statistika.

Pembelajaran berbasis proyek (PBP) menggunakan proyek sebagai media pembelajaran. Pembelajaran ini melibatkan mahasiswa dalam kegiatan pemecahan masalah dan tugas bermakna lainnya, memberi peluang mahasiswa bekerja secara otonom mengkonstruksi belajar mereka sendiri dan menghasilkan karya mahasiswa. PBP mengembangkan kemampuan berpikir tingkat tinggi, partisipasi aktif mahasiswa, memberikan kesempatan, melakukan penyelidikan, mengumpulkan data, melakukan analisis dan menarik kesimpulan. Baran \& Maskan (2010).

Lanali (2015) menjelaskan untuk mengembangkan kemampuan penalaran statistis siswa, guru dapat memberikan kesempatan kepada siswa bekerja dengan data nyata, mengartikulasikan alasannya melalui komunikasi tertulis atau lisan. Siswa yang diajarkan penanganan data statistik yang bersifat nyata dengan melaksanakan proyek masalah statistik, lebih siap untuk berkomunikasi statistik.

Setiap siswa memiliki kemampuan kognitif yang berbeda-beda. Selain berbeda dalam tingkat memecahkan masalah, taraf kecerdasan, atau kemampuan berpikir kreatif, siswa juga dapat berbeda dalam cara memperoleh, menyimpan serta menerapkan pengetahuan. Seseorang memiliki cara yang berbeda dalam mencari dan memproses informasi, serta melihat dan menginterpretasikannya. Perbedaan cara seseorang dalam memproses informasi tersebut dikenal dengan istilah gaya kognitif 
Gaya kognitif merupakan cara seseorang memproses dan mengolah informasi yang diterima untuk dapat digunakan dalam menyelesaikan permasalahan. Gaya kognitif berhubungan dengan bentuk aktivitas kognitif seperti pemikiran, perasaan, pemecahan masalah, dan lain-lain. Nurmalia (2019).

Inayah (2016) menyatakan beberapa hasil penelitian menunjukkan bahwa gaya kognitif seseorang mempengaruhi hasil belajarnya. Gaya kognitif ini menggambarkan kebiasaan tetap dalam diri mahasiswa dalam menerima, memikirkan, memproses dan mengorganisasi informasi yang diterimanya.

Putra (2013) menyatakan terdapat korelasi positif dan secara statistik signifikan antara gaya kognitif dan prestasi belajar. Selain itu, Una (2013) menyimpulkan terdapat hubungan positif antara gaya kognitif siswa dengan hasil belajar matematik, semakin tinggi gaya kognitif siswa (semakin banyak siswa yang memilki gaya kognitif FI yaitu gaya kognitif yang cenderung menyukai analisis dan pemecahan masalah), maka semakin tinggi pula hasil belajar siswa pada mata pelajaran matematika.

Menimbang bahwa gaya kognitif merupakan salah satu faktor yang mempengaruhi hasil belajar siswa maka penelitian ini dipandang perlu dilakukan. Penelitian ini bertujuan melihat bagaimana gaya kognitif mempengaruhi kemampuan penalaran dan komunikasi statistik mahasiswa. Berdasarkan latar belakang masalah, maka masalah yang akan diuraikan dalam penelitian ini adalah : (a) Apakah terdapat perbedaan peningkatan kemampuan penalaran statistik antara mahasiswa yang memiliki gaya kognitif FI dan FD (b) Apakah terdapat perbedaan peningkatan kemampuan komunikasi statistik antara mahasiswa yang memiliki gaya kognitif FI dan FD (c) Apakah terdapat korelasi antara kemampuan penalaran statistik mahasiswa dan kemampuan komunikasi statistik mahasiswa.

\section{B. Metode Penelitian}

Penelitian ini merupakan penelitian quasi experimental research design. Unit penelitian ditentukan berdasarkan gaya kognitif. Gaya kognitif dibedakan atas gaya kognitif fild dependent (FI) dan gaya kognitif Field independent (FI). Rancangan eksperimen yang digunakan adalah one group only pretest-posttest design. 
Tabel 1 Desain penelitian

\begin{tabular}{|c|c|c|c|}
\hline Gaya Kognitif & Pretest & Perlakuan & Posttest \\
\hline Gaya Kognitif Field independent & $\mathrm{O}_{1}$ & $\mathrm{X}$ & $\mathrm{O}_{3}$ \\
Gaya Kognitif Field dependent & $\mathrm{O}_{2}$ & & $\mathrm{O}_{4}$ \\
\hline
\end{tabular}

Sebelum melaksanakan pembelajaran terlebih dahulu dilakukan persiapan diantaranya: (1) Mengembangkan perangkat pembelajaran meliputi Bahan Ajar, SAP dan Silabus perkuliahan yang mengacu pada kulikulum yang berlaku di UMK. (2) Mengembangkan instrumen berupa tes GEFT, tes kemampuan penalaran statistik, tes kemampuan komunikasi statistik. Instrumen tersebut terlebih dahulu divalidasi oleh validator untuk menilai unsur kelayakannya instrumen dan menilai kesesuaian dengan indikator yang akan diukur. (3) Melakukan pengukuran gaya kognitif (GEFT) mahasiswa sebelum diberikan perlakuan berupa pembelajaran statistika inferensial dengan model pembelajaran berbasis proyek (PBP). memberikan pretes untuk mengetahui kemampuan awal penalaran dan komunikasi statistik mahasiswa (4) Melaksanakan Pembelajaran PBP dengan meninjau gaya kognitif mahasiswa. (5) Memberikan postes untuk mengetahui kemampuan akhir penalaran dan komunikasi statistik mahasiswa setelah mendapatkan pembelajaran PBP.

\section{Hasil dan Pembahasan}

\section{Deskripsi Kemampuan Penalaran Statistik}

Rerata skor pretes, postes dan N-gain kemampuan penalaran statistik mahasiswa dapat dinyatakan dalam gambar berikut:

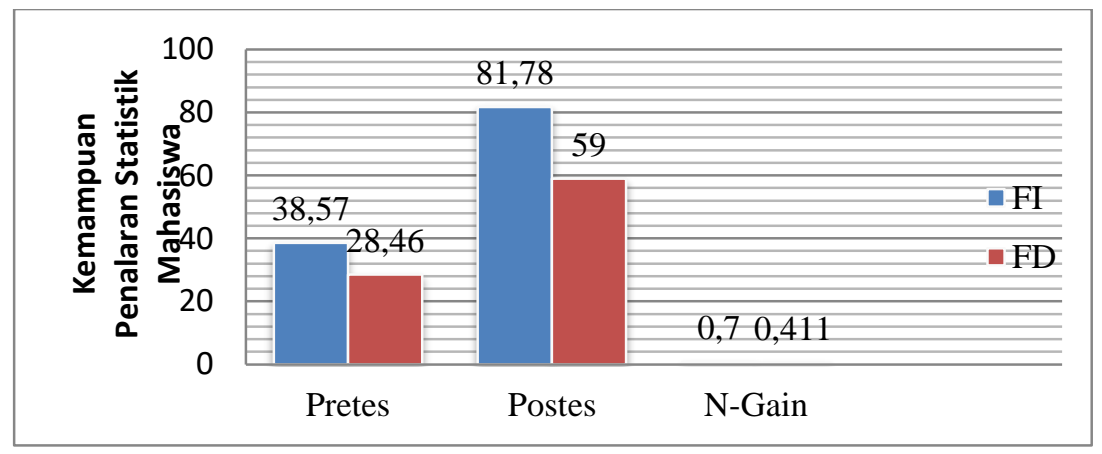

\section{Gambar 1. Rerata Skor Pretes, Postes dan N-Gain Kemampuan Penalaran Statistik Mahasiswa}

Berdasarkan gambar 1, diketahui bahwa rerata skor pretes mahasiswa FI sebesar 38,57 dengan standar deviasi 9,078 dan mahasiswa FD memperoleh skor pretes sebesar 28,46 dengan standar deviasi 9,657. Simpangan baku pretes FD lebih besar dari pretes FI mengindikasikan bahwa variasi skor awal mahasiswa 
FD lebih beragam dibandingkan mahasiswa FI. Secara deskriptif kemampuan awal penalaran statistik mahasiswa FI dan FD tidak jauh berbeda.Skor postes mahasiswa FI sebesar 81,78 dengan standar deviasi 11,53 dan mahasiswa FD memperoleh skor postes sebesar 59,00 dengan standar deviasi 8,29. Simpangan baku postes FI lebih besar dari postes FD mengindikasikan bahwa variasi skor akhir mahasiswa FI masih lebih beragam dibandingkan mahasiswa FD. Disimpulkan capaian kemampuan penalaran statistik mahasiswa FI dan FD jauh berbeda.

Peningkatan kemampuan penalaran statistik mahasiswa dapat dilihat dari Data N-Gain. Adapun rerata N-gain mahasiswa FI sebesar 0,70 dengan standar deviasi 0,180 dan mahasiswa FD sebesar 0,411 dengan standar deviasi 0,166. Data tersebut menunjukkan bahwa rerata peningkatan kemampuan penalaran statistik mahasiswa FI lebih tinggi daripada mahasiswa FD. Klasifikasi N-gain untuk mahasiswa FI berada pada kategori tinggi dan N-gain untuk mahasiswa FD berada pada kategori sedang. Dengan melihat rerata peningkatan kemampuan penalaran statistik mahasiswa yang memiliki gaya kognitif FI dan FD, disimpulkan peningkatan kemampuan penalaran mahasiswa FI lebih baik dari mahasiswa FD.

\section{Deskripsi Kemampuan Komunikasi Statistik}

Rerata skor pretes, postes dan N-gain kemampuan komunikasi statistik mahasiswa dapat dinyatakan dalam gambar berikut:

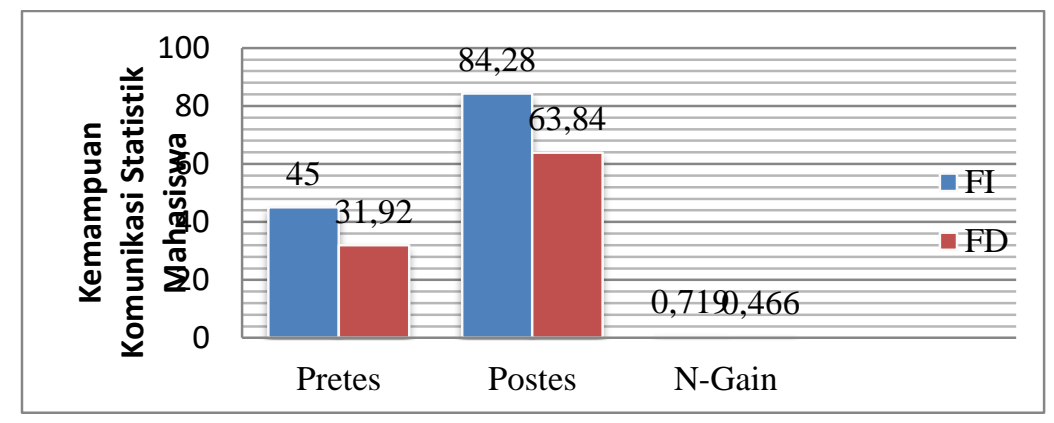

Gambar 2. Rerata Skor Pretes, Postes dan N-Gain Kemampuan Komunikasi Statistik Mahasiswa

Berdasarkan gambar 2, diketahui bahwa rerata skor pretes mahasiswa FI sebesar 45,00 dengan standar deviasi 10,00 dan mahasiswa FD memperoleh skor pretes sebesar 31,92 dengan standar deviasi 8,046. Simpangan baku pretes FI 
lebih besar dari pretes FD mengindikasikan bahwa variasi skor awal mahasiswa FI lebih beragam dibandingkan mahasiswa FD. Secara deskriptif kemampuan awal komunikasi statistik mahasiswa FI dan FD tidak jauh berbeda. Skor postes mahasiswa FI sebesar 84,28 dengan standar deviasi 10,53 dan mahasiswa FD memperoleh skor postes sebesar 63,84 dengan standar deviasi 9,822 Simpangan baku postes FI lebih besar dari postes FD mengindikasikan bahwa variasi skor akhir mahasiswa FI masih lebih beragam dibandingkan mahasiswa FD. Disimpulkan bahwa capaian kemampuan komunikasi statistik mahasiswa FI dan FD jauh berbeda.

Peningkatan kemampuan komunikasi statistik mahasiswa dapat dilihat dari Data N-Gain. Adapun rerata N-gain mahasiswa FI sebesar 0,719 dengan standar deviasi 0,170 dan mahasiswa FD sebesar 0,466 dengan standar deviasi 0,142. Data tersebut menunjukkan bahwa rerata peningkatan kemampuan komunikasi statistik mahasiswa FI lebih tinggi daripada mahasiswa FD. Klasifikasi N-gain untuk mahasiswa FI berada pada kategori tinggi dan N-gain untuk mahasiswa FD berada pada kategori sedang. Dengan melihat rerata peningkatan kemampuan penalaran statistik mahasiswa yang memiliki gaya kognitif FI dan FD, disimpulkan peningkatan kemampuan penalaran mahasiswa FI lebih baik dari mahasiswa FD.

\section{Analisis data peningkatan kemampuan penalaran mahasiswa FI dan FD}

Uji normalitas dimaksudkan untuk melihat apakah data yang diperoleh berasal dari populasi yang berdistribusi normal atau berdistribusi tidak normal.

Tabel 2 Tests of Normality

\begin{tabular}{|r|l|r|r|r|r|r|r|}
\hline & G_kogniti & \multicolumn{3}{|c|}{ Kolmogorov-Smirnov } & \multicolumn{3}{|c|}{ Shapiro-Wilk } \\
\cline { 3 - 8 } & f & Statistic & df & \multicolumn{1}{c|}{ Sig. } & Statistic & \multicolumn{1}{c|}{ df } & \multicolumn{1}{c|}{ Sig. } \\
\hline \multirow{2}{*}{ N_Gain_Penalaran } & FI &, 233 & 14 &, 039 &, 915 & 14 &, 187 \\
& FD &, 178 & 13 &, $200^{*}$ &, 962 & 13 &, 788 \\
\hline
\end{tabular}

Skor N-gain kemampuan penalaran matematis mahasiswa FI dan FD memiliki Sig. (2-tailed) $>\alpha=0,05$ sehingga $\mathrm{H}_{0}$ diterima, dengan kata lain skor $\mathrm{N}$ gain mahasiswa FI dan FD berasal dari populasi yang berdistribusi normal. Selanjutnya dilakukan uji homogenitas untuk mengetahui apakah kedua sampel berasal dari populasi yang memiliki variansi yang sama (homogen) atau variansi yang tidak sama (tidak homogen). 
Tabel 3 Tests of Homogenity

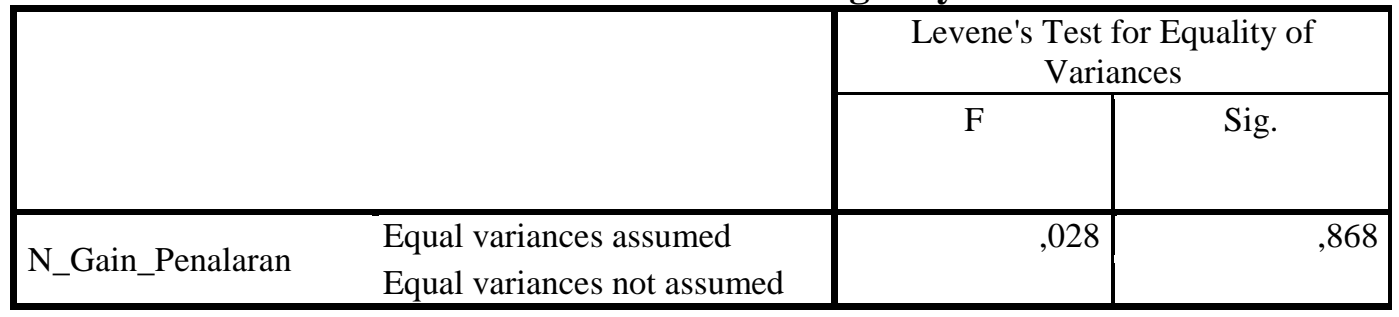

Berdasarkan Tabel 3, diperoleh nilai Sig. $>\alpha=0,05$, artinya $\mathrm{H}_{0}$ diterima, dengan kata lain variansi skor $\mathrm{N}$-gain kemampuan penalaran statistik mahasiswa FI dan FD homogen. Uji perbedaan rerata dilakukan untuk mengetahui apakah peningkatan kemampuan penalaran statistik mahasiswa FI tidak berbeda atau berbeda secara signifikan dengan kemampuan penalaran statistik mahasiswa FD. Karena data $\mathrm{N}$-gain menunjukkan data berdistribusi normal dan memiliki variansi yang sama (homogen), sehingga untuk menguji perbedaan dua rerata menggunakan uji parametrik yaitu uji-t.

Tabel 4 Data hasil uji perbedaan rerata skor $\mathrm{N}$-gain kemampuan penalaran statistik mahasiswa FI dan FD

\begin{tabular}{|c|c|c|c|c|c|c|c|c|}
\hline & \multicolumn{7}{|c|}{ t-test for Equality of Means } \\
\hline & & \multirow[t]{2}{*}{$\mathrm{t}$} & \multirow[t]{2}{*}{ df } & \multirow[t]{2}{*}{$\begin{array}{l}\text { Sig. (2- } \\
\text { tailed) }\end{array}$} & \multirow[t]{2}{*}{$\begin{array}{c}\text { Mean } \\
\text { Differenc } \\
\text { e }\end{array}$} & \multirow[t]{2}{*}{$\begin{array}{l}\text { Std. Error } \\
\text { Differenc } \\
\text { e }\end{array}$} & \multicolumn{2}{|c|}{$\begin{array}{l}95 \% \text { Confidence } \\
\text { Interval of the } \\
\text { Difference }\end{array}$} \\
\hline & & & & & & & Lower & Upper \\
\hline \multirow{2}{*}{$\begin{array}{l}\text { N_Gain_Pen } \\
\text { alaran }\end{array}$} & $\begin{array}{l}\text { Equal variances } \\
\text { assumed }\end{array}$ & 4,443 & 25 &, 000 & ,297592 & ,066987 &, 159629 & ,435555 \\
\hline & $\begin{array}{l}\text { Equal variances } \\
\text { not assumed }\end{array}$ & 4,457 & $\begin{array}{r}24,99 \\
9\end{array}$ &, 000 & ,297592 & ,066774 &, 160067 & ,435116 \\
\hline
\end{tabular}

Dari hasil uji perbedaan rerata N-gain diperoleh nilai Sig. (2-tailed) $<\alpha=$

0,05 sehingga $\mathrm{H}_{0}$ ditolak, artinya terdapat perbedaan yang signifikan peningkatan kemampuan penalaran statistik mahasiswa FI dan FD. Hal ini mengindikasikan bahwa peningkatan kemampuan penalaran statistik mahaiswa FI lebih baik daripada peningkatan kemampuan penalaran statistik mahasiswa FD.

\section{Analisis data peningkatan kemampuan komunikasi mahasiswa FI dan FD}

Uji normalitas dimaksudkan untuk melihat apakah data yang diperoleh berasal dari populasi yang berdistribusi normal atau berdistribusi tidak normal.

Tabel 5 Tests of Normality

\begin{tabular}{|l|l|r|r|r|r|r|r|}
\hline & G_kogniti & \multicolumn{3}{|c|}{ Kolmogorov-Smirnov $^{\mathrm{a}}$} & \multicolumn{3}{|c|}{ Shapiro-Wilk } \\
\cline { 3 - 8 } & $\mathrm{f}$ & Statistic & \multicolumn{1}{c|}{ df } & \multicolumn{1}{c|}{ Sig. } & Statistic & \multicolumn{1}{c|}{ df } & \multicolumn{1}{c|}{ Sig. } \\
\hline N_Gain_komunikas & FI &, 125 & 14 &, $200^{*}$ &, 968 & 14 &, 847 \\
$\mathrm{i}$ & FD &, 120 & 13 &, $200^{*}$ &, 954 & 13 &, 654 \\
\hline
\end{tabular}


Skor N-gain kemampuan komunikasi matematis mahasiswa FI dan FD memiliki Sig. (2-tailed) $>\alpha=0,05$ sehingga $\mathrm{H}_{0}$ diterima, dengan kata lain skor $\mathrm{N}$ gain kemampuan komunikasi statistik mahasiswa FI dan FD berasal dari populasi yang berdistribusi normal. Selanjutnya dilakukan uji homogenitas untuk mengetahui apakah kedua sampel berasal dari populasi yang memiliki variansi yang sama (homogen) atau variansi yang tidak sama (tidak homogen).

Tabel 6 Tests of Homogenity

\begin{tabular}{|ll|r|r|r|r|}
\hline & & Levene Statistic & \multicolumn{1}{|c|}{ df1 } & \multicolumn{1}{|c|}{ df2 } & \multicolumn{1}{c|}{ Sig. } \\
\hline \multirow{5}{*}{ N_Gain_komunikasi } & Based on Mean & 1,081 & 1 & 25 &, 308 \\
& Based on Median & 1,117 & 1 & 25 &, 301 \\
& Based on Median and with & 1,117 & 1 & 24,683 &, 301 \\
& adjusted df & & & & \\
& Based on trimmed mean & 1,103 & 1 & 25 &, 304 \\
\hline
\end{tabular}

Berdasarkan Tabel 6, diperoleh nilai Sig. $>\alpha=0,05$, artinya $\mathrm{H}_{0}$ diterima, dengan kata lain variansi skor N-gain kemampuan komunikasi statistik mahasiswa FI dan FD homogen. Uji perbedaan rerata dilakukan dengan tujuan untuk mengetahui apakah peningkatan kemampuan komunikasi statistik mahasiswa FI tidak berbeda atau berbeda secara signifikan dengan kemampuan komunikasi statistik mahasiswa FD. Data N-gain menunjukkan data berdistribusi normal dan memiliki variansi yang sama (homogen), sehingga untuk menguji perbedaan dua rerata dilakukan uji parametrik yaitu uji-t

Tabel 7 Data uji perbedaan rerata skor N-gain kemampuan komunikasi statistik mahasiswa FI dan FD

\begin{tabular}{|c|c|c|c|c|c|c|c|c|}
\hline & & \multicolumn{7}{|c|}{ t-test for Equality of Means } \\
\hline & & \multirow[t]{2}{*}{$\mathrm{t}$} & \multirow[t]{2}{*}{$\mathrm{df}$} & \multirow[t]{2}{*}{$\begin{array}{l}\text { Sig. }(2- \\
\text { tailed) }\end{array}$} & \multirow[t]{2}{*}{$\begin{array}{c}\text { Mean } \\
\text { Differen } \\
\text { ce }\end{array}$} & \multirow{2}{*}{$\begin{array}{c}\text { Std. } \\
\text { Error } \\
\text { Differen } \\
\text { ce }\end{array}$} & \multicolumn{2}{|c|}{$\begin{array}{l}95 \% \text { Confidence } \\
\text { Interval of the } \\
\text { Difference }\end{array}$} \\
\hline & & & & & & & Lower & Upper \\
\hline \multirow{2}{*}{$\begin{array}{l}\text { N_Gain_kom } \\
\text { unikasi }\end{array}$} & $\begin{array}{l}\text { Equal variances } \\
\text { assumed }\end{array}$ & 4,152 & 25 & ,000 &, 252593 &, 060831 &, 127309 & ,377877 \\
\hline & $\begin{array}{l}\text { Equal variances } \\
\text { not assumed }\end{array}$ & 4,181 & $\begin{array}{r}24,74 \\
6\end{array}$ &, 000 & ,252593 &, 060417 & ,128097 & ,377089 \\
\hline
\end{tabular}

Dari hasil uji perbedaan rerata $\mathrm{N}$-gain diperoleh nilai Sig. (2-tailed) $<\alpha=$ 0,05 sehingga $\mathrm{H}_{0}$ ditolak, Artinya terdapat perbedaan yang signifikan peningkatan kemampuan komunikasi statistik mahasiswa FI dan FD. Hal ini mengindikasikan bahwa peningkatan kemampuan statistik mahaiswa FI lebih baik daripada peningkatan kemampuan penalaran statistik mahasiswa FD.

Dengan kata lain gaya kognitif dan PBP memiliki pengaruh terhadap peningkatan kemampuan penalaran dan juga komunikasi statistik mahasiswa. 


\section{E. Analisis korelasi kemampuan penalaran dan komunikasi statistik}

Uji normalitas merupakan uji prasyarat untuk dapat melakukan uji korelasi pearson product moment.

Tabel 8 Tests of Normality

\begin{tabular}{|l|r|r|r|r|r|r|}
\hline & \multicolumn{3}{|c|}{ Kolmogorov-Smirnov $^{\text {a }}$} & \multicolumn{3}{c|}{ Shapiro-Wilk } \\
\cline { 2 - 7 } & Statistic & df & \multicolumn{1}{c|}{ Sig. } & Statistic & df & \multicolumn{1}{c|}{ Sig. } \\
\hline postes_penalaran &, 204 & 27 &, 005 &, 930 & 27 &, 070 \\
postes_komunikasi &, 151 & 27 &, 117 &, 949 & 27 &, 207 \\
\hline
\end{tabular}

Dari Tabel 8 diperoleh bahwa skor postes kemampuan penalaran statistik dan komunikasi statistik mahasiswa Sig. (2-tailed) $>\alpha=0,05$ sehingga $\mathrm{H}_{0}$ diterima, dengan kata lain skor postes kemampuan penalaran statistik dan komunikasi statistik mahasiswa berasal dari populasi yang berdistribusi normal. Selanjutnya dilanjutkan dengan uji korelasi pearson product moment.

Tabel 9. Data uji kroelasi pearson product moment

\begin{tabular}{|ll|r|r|}
\hline & & Penalaran & Komunikasi \\
\hline \multirow{2}{*}{ Penalaran } & Pearson Correlation & 1 &, $683^{* *}$ \\
& Sig. (2-tailed) & &, 000 \\
& N & 27 & 27 \\
Komunika & Pearson Correlation &, $683^{* *}$ & 1 \\
si & Sig. (2-tailed) &, 000 & \\
& N & 27 & 27 \\
\hline
\end{tabular}

Koefisien korelasi pearson product moment $\mathrm{r}=0,683$ dan nilai $\mathrm{Sig}=$ $0,000<0,05$ maka $\mathrm{H}_{0}$ ditolak, hal ini berarti ada hubungan linear yang signifikan antara kemampuan penalaran dan komunikasi statistik mahasiswa Tingkat keeratan hubungan kemampuan penalaran statistik dan komunikasi statistik mahasiswa kuat, artinya semakin tinggi kemampuan komunikasi mahasiswa maka semakin tinggi pula kemampuan penalaran mahasiswa tersebut, demikian juga sebaliknya.

Berdasarkan hasil pengolahan data secara deskriptif dan statistik diperoleh hasil bahwa terdapat perbedaan peningkatan kemampuan penalaran statistik mahasiswa dengan gaya kognitif FI dan FD. Begitu juga dengan kemampuan komunikasi statistik mahasiswa. Rerata rank peningkatan kemampuan penalaran dan komunikasi statistik mahasiswa FI selalu lebih tinggi dari mahasiswa FD. Artinya bahwa selain faktor metode pembelajaran, gaya kognitif juga berpengaruh terhadap peningkatan kemampuan penalaran dan komunikasi statistik mahasiswa. 
PBP adalah metode pembelajaran yang digunakan untuk meningkatkan kemampuan penalaran statistis mahasiswa. Penerapan PBP memiliki dampak atau berkontribusi terhadap terbentuknya kemampuan penalaran statistis mahasiswa. Melalui PBP mahasiswa aktif berinteraksi dengan temannya, mengkaji konsep statistika, menganalisis, menginterpretasi, menarik kesimpulan, dan memberikan komentar kritis terhadap proyek statistik yang dibahas secara kolaboratif. Saat mempresentasikan proyek kelompok mahasiswa dapat menjelaskan hasil kerja kelompoknya kepada mahasiswa lainnya dan terjadi interaksi tanya jawab antar mahasiswa. Interaksi ini menciptakan aktivitas berpikir dan bernalar yang memicu terjadinya adaptasi pikiran pada mahasiswa. PBP mengantarkan mahasiswa untuk saling tukar pendapat, saling melengkapi pengetahuan, meningkatkan motivasi belajar, memahami masalah, dan dapat mengukur kemampuan penalaran statistik berdasarkan gaya kognitif masing-masing yang berkontribusi terhadap pencapaian dan peningkatan kemampuan penalaran statistik mahasiswa.

Thomas (2000) menyatakan fokus penerapan PBP terletak pada konsepkonsep dan prinsip-prinsip inti dari suatu disiplin ilmu, melibatkan mahasiswa dalam investigasi pemecahan masalah, kegiatan tugas-tugas bermakna, dan memberi kesempatan kepada mahasiswa bekerja secara otonom untuk mengkonstruksi pengetahuan dan menghasilkan produk nyata sehingga mendorong tumbuhnya kreativitas, kemandirian, tanggung jawab, kepercayaan diri, berpikir kritis dan analitis yang akan berperan dalam peningkatan kemampuan penalaran statistik mahasiswa.

Penerapan PBP ini melibatkan mahasiswa dalam kegiatan tugas bermakna, dan mengkonstruksi kemampuannya untuk menghasilkan suatu produk untuk dievaluasi. Proses kegiatan pembelajaran tersebut sesuai rekomendasi Baran \& Maskan (2010) bahwa pembelajaran berbasis proyek dapat mendorong partisipasi mahasiswa untuk mencari, mengumpulkan data, melakukan analisis dan menarik kesimpulan dari suatu hasil analisis sehingga terciptanya pengembangan kemampuan berpikir tingkat tinggi.

Proyek dalam PBP dibahas secara kolaboratif dalam diskusi kelompok yang mengarahkan mahasiswa untuk belajar bermakna. Hal ini sesuai dengan prinsip pembelajaran berbasis proyek yang menjadikan masalah sebagai strategi 
pembelajaran, menginstruksikan mahasiswa agar dapat berusaha untuk mencari pemecahan masalah sesuai pengetahuan yang dimilikinya untuk menghasilkan pengetahuan baru yang bermakna. Interaksi mahasiswa dengan sumber informasi dalam PBP sesuai dengan teori belajar sosial bahwa penciptaan lingkungan belajar kolaboratif mengantarkan setiap mahasiswa berusaha menemukan konsep-konsep untuk menyelesaikan proyek masalahnya.

Hal ini menunjukkan bahwa mahasiswa secara aktif membangun pengetahuan, mengaitkan informasi baru pada konsep-konsep relevan yang terdapat dalam struktur kognitifnya yang berkontribusi terhadap pencapaian dan peningkatan kemampuan komunikasi statistik mahasiswa. Garfield (2002) menyatakan bahwa pembelajaran dengan memberikan kesempatan kepada siswa untuk bekerja dengan data nyata, mengartikulasikan gagasan melalui komunikasi tertulis atau lisan secara rutin, mendiskusikan berbagai solusi masalah statistik, membandingkan hasil interpretasi atau asumsi, dan membangun pengetahuan dengan pengetahuan "dunia nyata" dalam pemecahan masalah statistik dapat membantu siswa meningkatkan kemampuan komunikasi statistis. Berikut perbedaan kemampuan penalaran statistik dan komunikasi statistik ditinjau berdasarkan gaya kognitif mahasiswa.

Tabel 10 Perbedaan kemampuan penalaran statistik mahasiswa FI dan FD

\begin{tabular}{|c|c|c|c|}
\hline \multirow[t]{2}{*}{ No } & \multirow{2}{*}{$\begin{array}{ll}\text { Indikator } & \text { kemampuan } \\
\text { penalaran statistik }\end{array}$} & \multicolumn{2}{|c|}{ Gaya kogntif } \\
\hline & & FI & FD \\
\hline 1 & $\begin{array}{l}\text { Menggunakan pola hubungan } \\
\text { untuk menganalisis situasi, } \\
\text { atau membuat analogi, } \\
\text { generalisasi, dan menyusun } \\
\text { konjektur. }\end{array}$ & $\begin{array}{l}\text { Dapat menganalisis situasi mengenai } \\
\text { teknik analisis data yang digunakan } \\
\text { untuk kebutuhan penelitian tertentu, } \\
\text { menjelaskan secara tepat dengan alasan } \\
\text { yang rasional. }\end{array}$ & $\begin{array}{l}\text { Tidak jelas dalam } \\
\text { mengemukakan analisisnya } \\
\text { mengenai teknik analisis data } \\
\text { yang digunakan untuk } \\
\text { kebutuhan penelitian tertentu, } \\
\text { alasan berbelit dan kurang tepat }\end{array}$ \\
\hline 2 & $\begin{array}{l}\text { Memberi penjelasan terhadap } \\
\text { model, fakta sifat, hubungan, } \\
\text { atau pola. }\end{array}$ & $\begin{array}{l}\text { Dapat menjelaskan dengan baik dan } \\
\text { jelas pola koefisien korelasi yang } \\
\text { diberikan dengan keterangan yang } \\
\text { lengkap. }\end{array}$ & $\begin{array}{l}\text { Dapat menjelaskan dengan baik } \\
\text { dan jelas pola koefisien korelasi } \\
\text { yang diberikan tetapi kurang } \\
\text { lengkap. }\end{array}$ \\
\hline 3 & $\begin{array}{l}\text { Mengikuti aturan inferensi, } \\
\text { memeriksa validitas argumen, } \\
\text { membuktikan dan menyusun } \\
\text { argumen yang valid. }\end{array}$ & $\begin{array}{l}\text { Dapat melakukan perhitungan dengan } \\
\text { benar dan membuktikan bahwa } \\
\text { terdapat hubungan yang sangat kuat } \\
\text { antara pengalaman mengajar dan } \\
\text { kinerja guru melalui koefisien korelasi } \\
\text { yang positif dengan angka yang besar } \\
\text { medekati } 1\end{array}$ & $\begin{array}{l}\text { Menyimpulkan suatu argumen } \\
\text { tanpa melakukan perhitungan } \\
\text { terlebih dahulu, artinya } \\
\text { kesimpulan yang diperoleh } \\
\text { hanya berdasarkan perkiraan } \\
\text { atau insting masing-masing. }\end{array}$ \\
\hline
\end{tabular}


Tabel 11 Perbedaan kemampuan komunikasi statistik mahasiswa FI dan FD

\begin{tabular}{|c|c|c|c|}
\hline \multirow[t]{2}{*}{ No } & \multirow{2}{*}{$\begin{array}{l}\text { Indikator kemampuan } \\
\text { komunikasi statistik }\end{array}$} & \multicolumn{2}{|c|}{ Gaya kogntif } \\
\hline & & Uaya kog & FD \\
\hline 1 & $\begin{array}{l}\text { Menjelaskan idea, situasi, dan } \\
\text { relasi matematis secara tulisan } \\
\text { dengan benda nyata, gambar, } \\
\text { grafik atau Aljabar }\end{array}$ & $\begin{array}{l}\text { Dapat menuliskan rumusan hipotesis } \\
\text { statistik dengan tepat disertai penulisan } \\
\text { simbol matematis yang tepat }\end{array}$ & $\begin{array}{l}\text { Dapat menuliskan rumusan } \\
\text { hipotesis statistik dengan tepat } \\
\text { namun penulisan simbol } \\
\text { matematisnya kurang tepat }\end{array}$ \\
\hline 2 & $\begin{array}{l}\text { Menghubungkan } \\
\text { nyata dalam bentuk gambar, } \\
\text { diagram atau tabel ke dalam } \\
\text { ide statistik }\end{array}$ & $\begin{array}{l}\text { Dapat membuat rumusan hipotetsis } \\
\text { penelitian dan statistik dari masalah } \\
\text { nyata yang diberikan dan dapat } \\
\text { memberikan kesimpulan hasil uji } \\
\text { statistik dari masalah nyata tersebut }\end{array}$ & $\begin{array}{l}\text { Salah dalam membuat rumusan } \\
\text { hipotetsis penelitian dan statistik } \\
\text { dari masalah nyata yang } \\
\text { diberikan, salah dalam } \\
\text { melakukan perhitungan uji } \\
\text { statistik dan tidak memberikan } \\
\text { kesimpulan apapun dari masalah } \\
\text { nyata yang diberikan }\end{array}$ \\
\hline 3 & $\begin{array}{l}\text { Menginterpretasikan dan } \\
\text { menjelaskan kembali hasil dari } \\
\text { suatu penyelesaian masalah } \\
\text { matematis }\end{array}$ & $\begin{array}{l}\text { Dapat menginterpretasikan, } \\
\text { menjelaskan dan mengomunikasikan } \\
\text { kembali hasil dari suatu prhitungan uji } \\
\text { hipotesis dengan benar dan lengkap }\end{array}$ & $\begin{array}{l}\text { Dapat menginterpretasikan, } \\
\text { menjelaskan dan } \\
\text { mengomunikasikan kembali } \\
\text { hasil dari suatu prhitungan uji } \\
\text { hipotesis dengan benar dan } \\
\text { lengkap }\end{array}$ \\
\hline
\end{tabular}

Perbedaan kemampuan penalaran statistik diatas sejalan dengan Basir

(2015) menyatakan siswa FI tertarik pada problem solving dan lebih konsentrasi menyelesaikan suatu tugas dalam ruang lingkup sosial terbatas (sendiri) sebaliknya siswa FD memahami suatu masalah lebih unggul jika mengikuti aturan baku, mereka menyelesaikan masalah berdasarkan penalaran ulang (recall) dari informasi yang sudah disajikan oleh pengajar, tipe FD lebih nyaman belajar dalam kelompok dan memiliki pergaulan sosial yang luas. Individu yang memiliki gaya kognitif FI memiliki kemampuan unggul dalam hal analisa, strukturisasi, dan kemampuan penalaran sesuai dengan metode ilmiah, sedangkan individu yang memiliki gaya kognitif FD, lemah dalam strukturisasi dan pemecahan masalah berdasarkan metode ilmiah, tipe ini lebih nyaman jika diberi banyak bimbingan dari orang lain. Dengan kata lain individu FI lebih unggul kemampuan penalarannya dibandingkan individu FD.

Perbedaan kemampuan komunikasi statistik sejalan dengan Nurmalia (2019) subjek FI adalah subjek yang sangat cepat dalam memberi respon, mengorganisasi informasi untuk menentukan strategi penyelesaian yang sesuai dan memberikan solusi yang tepat dengan menggunakan lambang matematika yang tepat, memiliki kemampuan menganalisa soal dan tidak banyak terpengaruh oleh faktor luar, mampu mencari informasi tambahan diluar konten atau menghubungkannya dengan konsep lain dan lebih suka menyelesaikan masalah 
secara mandiri. Kemampuan komunikasi matematis subjek FI yang tinggi disebabkan karena memiliki faktor-faktor yang mempengaruhi kemampuan komunikasi antara lain, pengetahuan prasayarat (prior knowledge), kemampuan membaca, diskusi, dan menulis, serta pemahaman matematik (mathematical knowledge). Gaya kognitif FD kesulitan dalam memproses informasi, cenderung menerima informasi secara utuh tidak mampu mereorganisirnya, sulit fokus pada salah satu aspek cenderung mengikuti tujuan yang sudah ada, dan memandang objek secara global. Selain itu, subjek FD memiliki orientasi sosial yang tinggi sehingga tampak ramah, baik hati, penuh kasih sayang terhadap orang lain, dan mengutamakan motivasi eksternal, lebih suka belajar berkelompok, masih membutuhkan bantuan dalam menyelesaikan permasalahan, dan memiliki orientasi sosial. Karena kemampuan FI yang lebih baik dalam mengorganisasikan informasi maka dapat disimpulkan individu FI lebih unggul kemampuan komunikasinya dibandingkan individu FD.

\section{Kesimpulan}

a) Terdapat perbedaan peningkatan kemampuan penalaran statistik antara mahasiswa yang memiliki gaya kognitif FI dan FD, peningkatan kemampuan penalaran statistik mahasiswa FI lebih baik daripada mahasiswa FD (b) Terdapat perbedaan peningkatan kemampuan komunikasi statistik antara mahasiswa yang memiliki gaya kognitif FI dan FD, peningkatan kemampuan komunikasi statistik mahasiswa FI lebih baik daripada mahasiswa FD (c) Terdapat korelasi yang kuat antara kemampuan penalaran statistik mahasiswa dan kemampuan komunikasi statistik mahasiswa dengan koefisien korelasi sebesar 0,683. Adapun saran dari penelitian ini, pada guru atau dosen matematika untuk melakukan pendekatan secara individual terhadap siswa atau mahasiswa dengan gaya kognitif FD agar lebih dibimbing dalam menganalisis informasi yang tersaji pada soal dan mengomunikasikan ide matematika atau statistika secara lisan dan tulisan, sedangkan siswa atau mahasiswa FI agar lebih dibimbing dalam mempertahankan argumen pada saat memecahkan masalah, bernalar dan berkomunikasi. Pada peneliti lain, apabila ingin melakukan penelitian sejenis pada siswa dengan gaya kognitif agar meneliti pada subjek lain atau menggunakan tipe gaya kognitif lainnya dengan pada masalah yang lebih luas. 


\section{Daftar Pustaka}

Baran, M. \& Maskan, A. (2010). The Effect of Project-Based Learning On PreService Physics Teachers' Electrostatic Achievements. Cypriot Journal of Educational Sciences, Vol 5, hal. 243-257.

Basir, Moch Abdul. 2015. Kemampuan Penalaran Siswa dalam Pemecahan Masalah Matematis Ditinjau dari Gaya Kognitif. Jurnal Pendidikan Matematika FKIP Unissula Volume 3 Nomor 1.

Garfield, J. \& Chance, B. (2000). Assessment in statistics education: Issues and challenges. Mathematical Thinking and Learning. Diakses dari http://citeseerx.ist.psu.edu/viewdoc/download?doi=10.1.1.473.8868\&rep=re p1\&type $=$ pdf

Haerudin. (2013). Pengaruh Pendekatan SAVI terhadap Kemampuan Komunikasi dan Penalaran Matematik serta Kemandirian Belajar Siswa SMP. Infinity. 2(2): 183-193.

Inayah, Nurul. (2016).Pengaruh Kemampuan Penalaran Matematis dan Gaya Kognitif terhadap Kemampuan Komunikasi dan Koneksi Pada materi statistika siswa SMA. journal of est, volume 2 nomor 2 hal. 74- 8074.

Lanani, Karman. (2015).Kemampuan penalaran statistis, komunikasi statistis dan academic help-seeking mahasiswa dalam pembelajaran berbasis proyek berbantuan ICT. Disertasi UPI Bandung.

Nurmalia. (2019). Analisis kemampuan komunikasi matematis ditinjau dari gaya kognitif pada siswa SMK. Journal of Authentic Research on Mathematics Education (JARME)Volume 1, No. 2, E-ISSN: 2655-7762.

Putra, A., Murti, B., dan Suriyasa, P. (2013). "Hubungan Gaya Kognitif dan Penalaran Verbal dengan Prestasi Belajar Mata Kuliah Anatomi II pada Mahasiswa Pendidikan Jasmani Kesehatan dan Rekreasi (Fakultas Olahraga Dan Kesehatan Universitas Pendidikan Ganesha)". Jurnal Magister Kedokteran Keluarga, Volume 1 No. 1 pp. 92-103.

Sariningsih R, Herdiman I. (2017). Mengembangkan Kemampuan Penalaran Statistik dan Berpikir Kreatif Matematis Mahasiswa Melalui Pendekatan Open-ended. Jurnal Riset Pendidikan Matematika 4 (2), 2017, 239-246.

Thomas, J.W. (2000). A Review of Research On Project-Based Learning. Supported by The Autodesk Foundation 111 McInnis Parkway San Rafael, California. Diakses dari http://www.bie.org/research/study/review of project based learning 2000 .

Una, M. (2013). "Hubungan antara Gaya Kognitif Siswa dengan Hasil Belajar Matematika (Suatu Penelitian Survei dengan Pendekatan Korelasional pada Siswa VIII di SMP Negeri 1 Tilong Kabila Tahun Pelajaran 2012-2013)". Skripsi. Gorontalo: Universitas Negeri Gorontalo 